\title{
PERTANGGUNGJAWABAN KEPALA DESA DAN PERAN BADAN PERMUSYAWARATAN DESA
}

Oleh :

\author{
M. Sri Astuti Agustina \\ monicasriastuti1961@gmail.com
}

\begin{abstract}
Abstraksi :
Seiring berlakukannya otonomi daerah, perubahan terjadi dalam sistem pemerintahan desa. Didalam penyelenggaraan pemerintahan desa dan didalam pengelolaaan dana desa kepala desa harus menyampaikan pertanggung jawaban baik pada Pemerintah Kabupaten, maupun Kecamatan serta kepada Badan Permusyawaratan Desa, sesuai dengan aturan yangberlaku namun demikian dalam menyampaikan pertanggung jawaban tersebut banyak kendala yang ditemukan,dan dalam pertang gungjawaban kepala desa ini Badan Permusyawaratan desa mempunyai peran yang cukup penting,dan kendala yang terbesar dalam pertanggung jawaban Kepala desa dalam penggunaan dana desa adalah penyeleweng penggunaan dana desa, sehingga Pertanggungjawaban dana desa tidak bisa diterima. Hal Penting yang perlu mendapat perhatian segenap pelaku demokratisasi dan desentralisasi adalah adanya Badan Permusyawaratan Desa dalam struktur kelembagaan Pemerintah desa yang diatur dalam Undang Undang nomor 6 Tahun 2014 pasal 55 , tentang pemerintahan desa. Oleh karena itu,sangat bijak apabila Badan Permusyawaratan Desa memiliki fokus program dalam penguatan proses demokratisasi an disentralisasi Menuju terciptanya masyarakat dan pemerintahan yang baik dengan melaksanakan fungsi Pengawasannya.
\end{abstract}

\section{A. LATAR BELAKANG MASALAH}

Reformasi merupakan awal pengguliran demokratisasi dan desentralisasi Kehidupan berbangsa dan bernegara. dalam reformasi terkandung maksud bahwa sistem bernegara yang sentralistik sudah tidak mungkin Lakukan lagi. karena dengan sistem tersebut telah mengakibatkan berbagai Ketimpangan-ketimpangan yang terjadi di daerah dan berbasis pada sikap tidak puas daerah atas kebijakan yang dikeluarkan oleh Pusat.

Seiring berlakukannya otonomi daerah, perubahan terjadi dalam sistem pemerintahan desa. sebagai penyelenggara pemerintahan terkecil di daerah dinyatakan dalam "Undang-undang Nomor 5 Tahun 1979 tentang pemerintah desa (Lembaran negara Tahun 1979 nomor 56 tambahan lembaran negara nomor 3153) Yang 
diperbaharui dengan Undang Undang nomor 6 tahun 2014 tentang Pemerintahan desa menyeragamkan nama, bentuk, susunan pemerintahan desa.

Menurut pasal 1 ayat 2 Undang Nomor 6 Tahun 2014 tentang Pemerintah desa, Pemerintahan desa bisa diartikan Penyelenggaraan urusan pemerintahan dan kepentingan masyarakat setempat dalam sistem Pemerintahan Negara Republik Indonesia.

Pengertian di atas bahwa desa sebagai pemerintahan terbawah yang hak mengatur dan dan mengurus rumah tangga sendiri Perkataan lain, desa adalah sebuah daerah otonom. Tetapi Dengan daerah otonom tingkat I dan II, Otonomi desa tidak berasal dari pusat atau pemerintah daerah yang lebih luas.

Berlakunya undang-undang Nomor 6 Tahun tahun 2014 Diharapkan dapat mengatasi kekurangan dan kelemahan yang selama dalam sistem pemerintahan desa Sebagaimana diatur dalam undang-undang Nomor 5 Tahun 1979, secara signifikan dan secara substansi membawa perubahan pemerintahan desa sebagaimana diatur dalam pasal 95 Jo Pasal 104 undang-undang Nomor 22 Tahun 1999 diperbaharui dengan Undang Undang Nomor 23 tahun 2014 tentang pemerintahan daerah, dapat melengkapi kekurangan dan kelemahan Lembaga masyarakat desa, karena kedudukan, tugas, wewenang, fungsi, hak dan kewajiban badan perwakilan desa Sangatlah tegas dan jelas sehingga mempunyai posisi tawar terhadap pemerintah Desa yang dipimpin oleh Kepala Desa. Selain itu status anggota Badan Permusyawaratan Desa secara hukum mempunyai kedudukan setingkat Pemerintah desa.

Kebijakan otonomi ini betul-betul dijalankan danTerealisir, Maka daerah akan memperoleh kewenangan yang luas untuk mengelola Segala potensi. bersamaan dengan itu, pada daerah yang bertanggung jawab dalam berbagai hal, meliputi pemanfaatan, pemberdayaan dan sekaligus pengawasan. Disamping itu, Arah juga mempunyai tugas Membina dan melayani masyarakat tidak terkecuali di tingkat kabupaten/ kota, kecamatan dan desa. Karena itu, jika di masa orde baru pembuatan keputusan dan kebijakan dibuat oleh pusat, maka pada era reformasi Kabupaten mempunyai kewenangan untuk mengatur urusan rumah tangga sendiri serta mengelola potensi sumber daya yang dimiliki oleh masing-masing daerah. Pendek kata dengan perimbangan antara pusat dan daerah, dalam kerangka negara kesatuan republik Indonesia Maka sistem otonomi merupakan pilihan tak terelakkan. 
Komitmen tersebut dituangkan dalam undang-undang nomor 22 tahun 1999 yang diperbaruhi dengan Undang Undang nomor 6 tahun 2014 tentang pemerintah daerah dan undang-undang Nomor 33 tahun 2004 tentang perimbangan keuangan pemerintah pusat dan daerah.

Didalam penyelenggaraan pemerintahan desa dan didalam pengelolaaan dana desa kepala desa harus menyampaikan pertanggung jawaban baik pada Pemerintah Kabupaten, maupun kecamatan serta kepada Badan Permusyawaratan Desa, sesuai dengan aturan yang berlaku namun demikian dalam menyampaikan pertanggungjawaban tersebut banyak kendala yang ditemukan, dan dalam pertanggungjawaban kepala desa ini Badan Permusyawaratan desa mempunyai peran yang cukup penting, dan kendala yang terbesar dalam pertanggungjawaban Kepala desa dalam penggunaan dana desa adalah penyelewengan penggunaan dana desa, sehingga Pertanggungjawaban dana desa tidak bisa diterima..

Hal Penting yang perlu mendapat perhatian segenap pelaku demokratisasi dan desentralisasi adalah adanya Badan Permusyawaratan Desa dalam struktur kelembagaan Pemerintah desa yang diatur dalam Undang Undang nomor 6 Tahun 2014 pasal 55 Badan permusyawaratan desa mempunyai 3 fungsi, yaitu:

1. Membahas dan menyepakati rancangan peraturan desa bersama kepala desa

2. Menampung dan menyalurkan aspirasi masyarakat

3. Melakukan pengawasan Kinerja Kepala Desa.

Oleh karena itu, sangat bijak apabila Badan permusyawaratan desa memiliki fokus program dalam penguatan proses demokratisasi dan disentralisasi Menuju terciptanya masyarakat dan pemerintahan yang baik. Berdasarkan Latar Latar permasalahan tersebut Penulis mengambil judul "PERTANGGUNGJAWABAN KEPALA DESA DAN PERAN BADAN PERMUSYAWARATAN DESA” dalam penulisan ini.

\section{B. PERUMUSAN MASALAH}

Mendasari pada latar belakang tersebut di atas maka penulis bermaksud membahas tentang permasalahan, yaitu :

1. Faktor faktor yang menjadi Kendala dalam Pertanggungjawaban Kepala Desa.

2. Bagaimana Peran Badan Pemusyawaratan Desa dalam kaitannya dengan Pertanggungjawaban Kepala Desa 


\section{TUJUAN PENULISAN}

1. Memahami peran Badan Permusyawaratan Desa dalam kaitannya dengan pertanggungjawaban kepala desa

2. Mengetahui dan memahami faktor apa saja yang menjadi penghambat pertanggungjawaban Kepala Desa

\section{METODE PENELITIAN}

Metode pedekatan yang dipakai dalam skripsi ini adalah Metode pendekatan yuridis Normatif yaitu dengan mempelajari buku buku literatur dan teori teori maupun undang undang yang berkaitan dengan permasalahan.

1. Sumber data

Data yang penulis gunakan dibedakan atas data primier dan data skunder.

a. Data primer, diperoleh Secara langsung dari informan.dari kepala desa, dan Badan Permusyawaratan Desa

b. Data skunder

Yaitu data Yang diperoleh pustakaan dalam bentuk buku-buku, diklat, perundang-undangan serta dokumen-dokumen yang berkaitan dengan permasalahan yang dibahas diatas.

2. Teknik pengumpulan data

Teknik pengumpulan data skripsi ini terdiri data dengan Studi kepustakaan dilakukan dengan cara membaca, mempelajari, merangkum serta mengutip peraturan perundang undangan, buku-buku literature, serta karya ilmiah yangberkaitan dengan penulisan ini.

\section{E. PENGERTIAN OTONOMI DAERAH}

Kata "otonomi" yang dalam bahasa Belanda disebut autonomie; zelftwetgeving; zelftwetgeving Yang berarti keadaan dimana pemerintah daerah mampu mengatur, membeli membiayai pelaksanaan pemerintah dengan budget daerah sendiri, tanpa adanya subsidi dari pemerintah pusat, daerah itu disebut daerah otonom atau disebut daerah swatantra. ${ }^{1}$

\footnotetext{
${ }^{1}$ Yan Pramadya Puspa, 1977: h 93
} 
Menurut Miriam Budiardjo Menjelaskan dalam bukunya Dasar Dasar Ilmu Politik; Bahwa Pemerintah Pusat mempunyai wewenang sebagian kekuasaannya ke daerah berdasarkan Hak Otonomi.Penyerahan sebagian kekuasaan itu karena Indonesia adalah negara kesatuan dengan system Desentralisasi.Namun pada tahap terakhir kekuasaan tertinggi tetap ada pada pemerintah pusat .

Oleh karena itu undang-undang nomor 5 tahun 1974 tentang pokok-pokok pemerintahan memberikan penegasan bahwa yang dimaksud dengan otonomi daerah adalah hak, wewenang untuk mengatur dan mengurus rumah tangganya sendiri sesuai dengan peraturan perundang-undangan yang berlaku. Sedangkan Dalam undang-undang nomor 32 tahun 2004 tentang pemerintah daerah pasal 1 butir (h) berbunyi :

Otonomi daerah adalah wewenang daerah otonom untuk mengatur dan mengurus kepentingan masyarakat setempat menurut prakarsa sendiri berdasarkan aspirasi sesuai dengan peraturan perundang-undangan.

Sedangkan atteng syafrifuddin berpendapat bahwa :

Dengan menitikberatkan otonomi pada Kabupaten, maka kabupaten yang dapat menjamin perkembangan Otonomi desa berangsur-angsur tercapai mengatur rumah tangganya sendiri di dalam arti yang sebenarnya (Ateng Syafrifuddin, $1991: 91$ )

Berdasarkan uraian di atas dapat diambil Suatu Pengertian bahwa otonomi daerah pada dasarnya pemberian kekuasaan kepada daerah dalam mengurus rumah tangganya sendiri .

\section{F. PENGERTIAN DESA, KEWENANGAN DAN PENYELENGGARAAN PEMERINTAHAN DESA}

\section{Pengertian Desa}

Adapun maksud dari pengertian desa adalah pengertian yang sering dipergunakan oleh masyarakat. Suhartono $(200 ; 10)^{2}$ berpendapat, sebagai tempat dimana bermukim Penduduk peradaban lebih terbelakang ketimbang kota .Dalam Kamus Besar Bahasa Indonesia (Dikbud,1988) Menyebutkan bahwa desa adalah a. yang merupakan kesatuan Kampung dan dusun,b. Udik atau dusun daerah pedalaman sebagai lawan kota dan c. tempat, tanah, dan daerah.Pengertian desa dalam Kecamatan hukum adat, menurut pendapata Soerjo Wignjodipoero (1995:19).

7. Suhartono, Otonomi Daerah, 2000 
Suatu desa (village) adalah "Suatu masyarakat wilayah yang organisasinya didasarkan pada tata urusan pusat yang berwibawa di seluruh lingkungan wilayahnya Suasana bertunggal wilayah terbesar dalam susunan rakyat yang merupakan organisasi pemerintahannya ${ }^{3}$

Dilihat dari Sudut pandang hukum dan politik, yang lebih menekankan kepada tata aturan yang menjadi dasar pengaturan kehidupan bermasyarakat, Desa dipahami sebagai "suatu daerah kesatuan hukum dimana bertempat tinggal suatu masyarakat yang berkuasa mengadakan pemerintahan sendiri" ${ }^{4}$.

Menurut undang-undang Nomor 22 Tahun 1999 tentang pemerintahan daerah (Lembaran negara tahun 1999 nomor 60, tambahan lembaran No 3839). Bab I, pasal I, butir (o): Jelaskan bahwa desa atau yang disebut dengan nama lain, desa kesatuan masa hukum yang memiliki kewenangan untuk mengenai mengatur dan mengurus kepentingan masyarakat setempat berdasarkan asal-usul dan adat istiadat setempat yang diakui dalam sistem pemerintahan nasional berada di kabupaten" (Depdargi, 1999:8). ${ }^{5}$

Pengertian Desa Menurut Undang Undang nomor 6 tahun 2014 pasal 1 ayat 1 tentang pemerintahan Desa : Desa adalah desa dan desa adat atau yang disebut dengan nama lain, selanjutnya disebut kesatuan masyarakat hukum yang memiliki batas wilayah yang berwenang untuk mengatur dan mengurus urusan Pemerintahan, kepentingan masyarakat setempat berdasarkan prakarsa masyarakat, Hak asal usul dan/atau hak tradisionil yang diakui dan dihormati dalam system pemerintahan republik Indonesia.

\section{Kewenangan Desa}

Menurut Undang Undang nomor 6 tahun 2014 pasal 18: Kewenangan desa meliputi kewenangan didalam penyelenggaraan pemerintahan desa, pelaksanaan pembangunan desa, pembinaan kemasyarakatan desa dan pemberdayaan masyarakat desa berdasarkan prakarsa masyarakat, hak asal ususl dan adat istiadat desa. Dalam pasal 19 Undang Undang nomor 6 Th 2014 tersebut diatas disebutkan bahwa Kewenangan desa meliputi :

\footnotetext{
${ }^{3}$ Imam Sudiat (2000:142

${ }^{4}$ Suhartono, 2000:13

${ }^{5}$ Depdargi, 1999:8
} 
a. Kewenangan berdasarkan hak asal usul

b. Kewengan lokal berskala desa

c. Kewengan yang ditugaskan oleh pemerintah, pemerintah daerah propinsi atau daerah pemerintah kabupaten/kota.

d. Kewenangan lain yang ditugaskan oleh pemerintah, pemerintah daerah propinsi atau daerah pemerintah kabupaten/kota sesuai dengan ketentuan peraturan perundang undangan.

Didalam pasal 22 ayat 1 diatur bahwa Penugasan dari Pemerintah dan/atau Pemerintah Daerah kepada desa meliputi Penyelenggaraan Pemerintah Desa, pelaksanaan pembangunan Desa, Pembinaan Kemasyarakatan desa dan Pemberdayaan masyarakat desa, ayat 2 ; penugasan sebagaimana dimaksud pada ayat 1 disertai biaya.

\section{Penyelenggaraan Pemerintahan Desa}

Menurut Undang Undang nomor 6 tahun 2014 penyelenggaraan pemerintahan desa adalah, Pelaksanaan pembangunan desa pembinaankemasyarakatan desa dan pemberdayaan masyarakat desa berdasar Pancasila dan Undang Undang Dasar Negara Republik Indonesia Th 1945, Negara Kesatuan R I dan Bhineka Tunggal Ika.

Berdasarkan Pasal 24 Undang undang nomor 6 tahun 2014 tentang Pemerintahan desa, penyelenggaraan pemerintahan desa berdasarkan :Asas :
a. Kepastian Hukum
b. Tertib Penyelenggaraan Pemerintahan desa
c. Tertip Kepentingan Umum
d. Keterbukaan
e. Proporsionalitas
f. Profesionalitas
g. Akuntabilitas
h. Efektifitas dan Efisiensi
i. Kearifan local
j. Keberagaman dan
k. Partisipasif. 
Jadi dalam asas kepastian hukum segala apa yang dilaksanakan oleh pemerintah desa harus berlandaskan atau berpegang pada aturan perundang undangan yang ada tidak melanggar perundang undangan, penyelenggaraan pemerintahan desa harus mengedepankan keadilan pada masyarakat tidak ada unsure pilih kasih atau membeda bedakan dan memperhatikan kepatutan dalam setiap kebijakan penyelenggaraan pemerintah desa.

\section{Kedudukan desa dalam pemerintah Kabupaten}

Seiring pelaksanaan undang-undang Nomor 23 Tahun 2014 tentang Pemerintahan daerah, dibutuhkan pemerintahan desa yang kuat dan Solid dalam mengemban amanat masyarakat.

sebagaimana telah disebutkan di atas, dalam pasal 1 Undang-undang otonomi daerah Dinyatakan desa adalah kesatuan hukum yang memiliki kewenangan untuk mengatur dan mengurus kepentingan masyarakat setempat berdasarkan asal usul dan adat istiadat setempat yang diakui dalam sistem pemerintahan nasional dan berada di daerah Kabupaten".

Ini terkandung maksud bahwa pemerintahan desa diharapkan tidak lagi mengalami kebimbangan dalam mengatur pemerintahannya, akan tetapi Bisa diharapkan mampu memberikan Dasar masyarakat berkembang. Karena itu, bisa tidak lagi merupakan level administrasi daerah menjadi masyarakat yang mandiri.

Dalam buku panduan Badan Permusyawaratan Desa Disebutkan bahwa pemerintah desa dalam sistem pemerintah Kabupaten adalah sebagi berikut :

1. Pemerintahan desa merupakan subsistem pemerintahan nasional dalam wadah NKRI yang memiliki kewenangan mengatur dan mengurus kepentingan masyarakat.

2. Peraturan pemerintahan desa tidak lagi diatur dengan undang-undang tersendiri, Undang Nomor 23 Tahun 2014 tentang pemerintahan daerah. pemerintah merupakan integral dari pemerintah daerah, termasuk pengaturan lebih lanjut.

3. Landasan pengaturan pemerintahan desa keanekaragaman, partisipasi otonomi asli, demokratisasi dan pemberdayaan masyarakat. Oleh karena 
itu hubungan pemerintahan Kabupaten dengan pemerintah Desa bukan berhubungan tetapi koordinatif.

4. Pemerintahan desa merupakan ujung tombak pemerintahan Kabupaten. pemerintahan desa menjadi pengayom, pembina, pelayan, dan pegarah partisipasi masyarakat ke arah pemberdayaan.

Dari konsepsi tersebut diatas dapat diambil suatu pengertian bahwa Pada dasarnya dengan adanya undang-undang nomor 6 tahun 2014 tentang pemerintahan daerah memberikan peluang yang lebih besar bagi pemerintahan desa untuk berkembang dan dan dalam rangka mewujudkan kemajuan bagi masyarakatnya.

Lebih lanjut Sadu Wasistiono berpendapat, bahwa Untuk mewujudkan otonomi daerah dalam pemerintahan paling sedikit ada 3 hal, yaitu :

1. Hak untuk mempunyai hukum atau aturan sendiri yang berlaku bagi kesatuan masyarakat hukum yang bersangkutan.

2. Hak untuk secara bebas memilih pimpinannya sendiri.

3. Hak untuk mempunyai kekayaan sendiri serta mempergunakannya untuk kepentingan bersama persatuan masyarakat hukum tersebut.

Dengan adanya otonomi daerah, semakin banyaknya yang bisa dilakukan pemerintah desa, yang pada akhirnya diharapkan membawa manfaat untuk kemajuan masyarakat setempat.

\section{Tugas Wewenang dan Fungsi Kepala desa}

Tugas dan wewenang kepala desa sesuai yang diatur dalam Undang Undang nomor 6 tahun 2014 tentang desa diatur dalam pasal 26 : kepala desa bertugas menyelenggarakan pemerintahan desa, melaksanakan pembangunan desa, pembinaan kemasyarakatan desa dan pemberdayaan masyarakat desa. Dalam melaksanakan tugas dimaksud Kepala Desa berwenang :

a. Memimpin penyelenggarakan pemerintahan desa

b. Mengangkat dan memberhentikan perangkat desa.

c. Memegang Kekuasaan pengelolaan keuangan dan asset desa.

d. Menetapkan peraturan desa.

e. Menetapkan Anggaran Pendapatan dan Belanja Desa

f. Membina Kehidupan masyarakat desa 
g. Membina ketentraman dan ketertipan masyarakat desa.

h. Membina dan meningkatkan perekonomian desa serta

i. Mengintergrasikan agar mencapai perekonomian skala produktif untuk sebesar besarnya kemakmuran masyarakat desa.

j. Mengembangkan sosial masysrakat desa.

k. Memanfaatkan tehnologi tepat guna

1. Mengkoordinasikan pembangunan desasecara partisipasif.

m. Mewakili desa didalam dan diluar pengadilan atau menunjuk kuasa hukum untuk mewakilinya sesuai dengan sesuai dengan ketentuan peraturan perundang undangan dana

n. Melaksanakan ketentuan lain yang sesuai dengan ketentuan perundang undangan.

Dalam melaksanakan tugas sebagaimana dimaksud Kepala Desa Ber Hak:

a. Mengusulkan Struktur organisasi dan tata kerja Pemerintahan Desa

b. Mengajukan Rancangan dan menetapkan peraturan desa.

c. Menerima penghasilan tetap setiap bulan, tunjangan dan penerimaan, lain Yang sah serta mendapat jaminan kesehatan.

d. Mendapat perlindungan hukum atas kebijaksanaan yang dilakukan

e. Memberikan mandate pelaksanaan tugas dan kewajiban lainnya kepada perangkat desa.

Menurut Permendagri No 84 tahun2015 tentang susunan Organisasi dan Tata Kerja Pemerintahan Desa pasal 6 sebagai berikut :

(1) Kepala Desa berkedudukan sebagi kepala pemerintahan desa yang memimpin penyelenggaraan Pemerintahan desa.

(2) Kepala Desa bertugas menyelenggarakan pemerintahan desa, melaksanakan pembangunan pembinaan kemasyarakatan dan pemberdayaan masyarakat.

(3) Untuk melaksanakan tugas sebagaimana dimaksud pada ayat 2 kepala desa memiliki fungsi fungsi sebagai berikut:

a. Menyelenggarakan Pemerintahan Desa seperti Tata Praja Pemerintahan, Penetapan peraturan di desa, pembinaan masalah pertanahan, pembinaan ketentraman, dan ketertipan, melakukan upaya perlindungan masyarakat, administrasi kependudukan, dan penataan serta pengelolaan wilayah. 
b. Melaksanakan pembangunan seperti pembangunan sarana prasarana, , perdesaan, dan pembangunan bidang pendidikan, kesehatan.

c. Pembinaan kemasyarakatan seperti pelaksanaan hak dan kewajiban masyarakat, partisipasi masyarakat, sosial budaya masyarakat, keagamaan dan ketenagakerjaan.

d. Pemberdayaan masyarakat seperti tugas sosialisasi dan motivasi masyarakat di bidang budaya, ekonomi, politik, lingkungan hidup, pemberdayaan keluarga, pemuda, olahraga dan karang taruna.

e. Menjaga hubungan kemitraan dengan lembaga masyarakat dan lembaga lainnya.

\section{G. PENGERTIAN DAN RUANG LINGKUP BADAN PERMUSYAWARATAN DESA}

\section{Pengertian Badan Permusyawaratan Desa}

Terbentuknya Badan Permusyawaratan Desa (BPD) bertujuan mendorong terciptanya partnership yang harmonis serta tidak konfrontatif antara kepala desa sebagai kepala pemerintah desa dan BPD sebagai wakil-wakil rakyat desa yang diperagakan oleh lembaga legislatif baik ditingkat kabupaten/kota, provinsi dan pusat.Kembalinya fungsi kontrol atas kekuasaan eksekutif desa, yang selama ini didominasi oleh kepala desa, sekarang fungsi kontrol atas kekuasaan eksekutif desa dijalankan oleh Badan Permusyaratan Desa (BPD) sebagai badan legislatif desa yang merupakan lembaga kepercayaan masyarakat. Lahirnya Badan Permusyaratan Desa (BPD), dinilai sebagai institusi politik demokrasi di masyarakat pedesaaan sebagai pengganti LMD yang memberikan suasana baru dalam kehidupan demokrasi di desa.

Penelitian ini bertujuan untuk mengkaji Bagaimana fungsi Badan Permusyaratan Desa (BPD) dalam pelaksanaan kerja pemmenggali lebih dalam bagaimana fungsi BPD itu sebenarnya di Desa dalam proses pemerintahan dan pembangunan. Disarankan perlu adanya koordinasi yang baik antara pemerintah Desa dan BPD, serta harus adanya anggaran khusus untuk BPD untuk menunjang operasionalnya

Seiring dengan adanya undang-undang nomor 6 tahun 2014 tentang pemerintahan daerah, salah satu kewenangan desa dalam mengatur dan mengurus pemerintahannya, Dibentuknya badan Permusyawaratan Desa atau sering disingkat dengan BPD. 
Sesuai Undang-undang Nomor 6 Tahun 2014

Menurut Wikipedia Badan Permusyawaratan Desa merupakan Lembaga Perwujudan Demokrasi dalam penyelenggaraan Pemerintahan Desa, BPD dapat dianggap sebagai Parlemennya desa BPD merupakan lembaga baru di era Otonomi daerah di Indonesia.

\section{Tugas, Wewenang dan fungsi Badan Permusyawaratan Desa}

Salah satu lembaga yang merupakan perwujudan Demokrasi dalam penyelenggaraan pemerintahan desa adalah Badan Permusyawaratan Desa (BPD)yang bisa juga disebut Badan Parlemen desa anggota BPD merupakan perwakilan dari penduduk desa yang bersangkutan berdasarkan keterwakilan wilayah yang ditetapkan secara musyawarah dan mufakat.

a.Tugas dan wewenang Badan Permusyawaratan Desa (BPD) menurut Permendagri nomor 110 tahun 2016, pasal 32. Sebagaai berikut :

1. Menggali Aspirasi masyarakat

2. Menampung aspirasi masyarakat

3. Mengelola aspirasi masyarakat

4. Menyalurkan Aspirasi masyarakat

5. Menyelenggarakan musyawarah BPD

6. Menyelenggarakan musyawarah Desa

7. Menyelenggarakan musyawarah Desa khusus untuk pemilihan desa antar waktu.

8. Membahas dan menyepakatiRancangan peraturan desa bersama kepala desa

9. Melaksanakan pengawasan terhadap kinerja kepala desa.

10. Melakukan Evaluasi laporan keterangan penyelengaraan pemerintahan desa.

11. Menciptakan hubungan kerja yang harmonis dengan pemerintah desa dan lembaga desa lainnya dan melaksanakan tugas lain yang diatur dalam ketentuan peraturan perundang undangan.

Menurut Undang Undang nomor 6 Tahun 2014 pasal 55 Badan permusyawaratan desa mempunyai 3 fungsi, yaitu:

1. Membahas dan menyepakati rancangan peraturan desa bersama kepala desa

2. Menampung dan menyalurkan aspirasi masyarakat 
3. Melakukan pengawasan Kinerja Kepala Desa.

Fungsi Badan Permusyawaratan Desa menurut Permendagri nomor 110 tahun 2016 adalah :

a. Membahas dan menyepakati Rancangan peraturan desa bersama kepala desa

b. Menampung dan menyalurkan aspirasi masyarakat desa dan

c. Melakukan pengawasan kinerja kepala desa.

\section{H. PENGERTIAN PERTANGgUNGJAWABAN DAN JENIS LAPORAN KEPALA DESA}

Berikut ini akan dikemukakan mengenai pengertian tanggung jawab, sebagai berikut: Menurut Kamus Besar Bahasa Indonesia (KBBI) tanggung jawab adalah kewajiban menanggung segala sesuatunya (bila terjadi apa-apa boleh dituntut, dipersalahkan dan diperkarakan dan sebagainya).

Ada dua istilah yang menunjuk pada pertanggung jawaban dalam kamus hukum, yaitu liability dan responsibility. Liability merupakan istilah hukum yang luas yang menunjuk hamper semua karakter risiko atau tanggung jawab, yang pasti, yang bergantung atau yang mungkin meliputi semua karakter hak dan kewajiban secara actual atau potensial seperti kerugian, ancaman, kejahatan, biaya atau kondisi yang menciptakan tugas untuk melaksanakan undang-undang.

Selanjutnya menurut Titik Triwulan pertanggung jawaban harus mempunyai dasar, yaitu hal yang menyebabkan timbulnya hak hokum bagi seseorang untuk menuntut orang lain sekaligus berupa hal yang melahirkan kewajiban hukum orang lain untuk memberi pertanggungjawabannya.

Menurut Sugeng Istanto pertanggung jawaban Negara adalah kewajiban Negara memberikan jawaban yang merupakan perhitungan atas suatu hal yang terjadi dan kewajiban untuk memberikan pemulihan atas kerugian yang mungkin ditimbulkan.

Sebagaimana layaknya dalam system hukum nasional, dalam hukum internasional juga dikenal adanya tanggungjawab sebagai akibat dari tidak dipenuhinya kewajibankewajiban menurut hokum internasional.[7] Ada dua pengertian dari pertanggung jawaban negara: pertama, pertanggung jawaban atas tindakan negara yang melanggar kewajiban internasionalnya. Kedua, pertanggung jawaban yang dimiliki oleh Negara atas pelanggaran terhadap orang asing. 
Laporan Kepala Desa (Kades) dan Laporan pertanggungjawabannya ada beberapa jenis yang telah diatur dalam undang-undang dan harus difahami oleh Perangkat Desa, Badan Permusyawaratan Desa (BPD) serta masyarakat.

Ada dua jenis laporan kepala desa yang paling pokok, yaitu Laporan Penyelenggaran Pemerintahan yang diatur dengan Peraturan Menteri Dalam Negeri (Permendagri) Nomor 46 tahun 2016, dan Laporan Realisasi Pelaksanaan Anggaran Pendapatan dan Belanja Desa (APBDesa) yang diatur dengan Peraturan Menteri Dalam Negeri (Permendagri) Nomor 20 tahun 2018.

Untuk memahami masing-masing jenis laporan dan pertanggungjawaban seorang Kepala Desa, mari kita coba uraikan satu per satu berikut ini :

a. Laporan Penyelenggaraan Pemerintahan Desa, sebagaimana dituangkan dalam pasal 2 Permendagri nomor 46 tahun 2016, dimana terdiri atas :

1. Laporan Penyelenggaraan Pemerintahan Desa (LPPD) akhir tahun anggaran, disampaikan kepada Bupati/Walikota melalui Camat.

2. Laporan Penyelenggaraan Pemerintahan Desa akhir masa jabatan (LPPDAJ), disampaikan kepada Bupati/Walikota melalui Camat

3. Laporan Keterangan Penyelenggaraan Pemerintahan Desa (LKPPD) akhir tahun anggaran, disampaikan kepada Badan Permusyawaratan Desa (BPD).

4. Informasi Penyelenggaraan Pemerintahan Desa (IPPD), disampaikan kepada masyarakat.

b. Laporan Realisasi Pelaksanaan Anggaran Pendapatan dan Belanja Desa (APBDesa), sebagaimana diuraikan dalam Peraturan Menteri Dalam Negeri Nomor 20 tahun 2018 yang terdiri atas :

1. Laporan Pelaksanaan (LP) Anggaran Pendapatan dan Belanja Desa (APBDesa) (pasal 68) yang terdiri atas:

- Laporan Pelaksanaan Anggaran Pendapatan dan Belanja Desa (APBDesa) semester 1 (pertama), di bulan Juli dan semester 2 (kedua) di bulan Januari tahun berikutnya.

- Laporan Realisasi Kegiatan (tiap Pelaksanaan Anggaran Kegiatan dalam per semester).

2. Laporan Pertanggungjawaban Realisasi Pelaksanaan (LPRP) Anggaran Pendapatan dan Belanja Desa (APBDesa) selambat-lambatnya 3 bulan setelah 
berakhir tahun anggaran (pasal 70), dalam bentuk Peraturan Desa (Perdes). Dimana terdiri atas :

a. Laporan Keuangan, terdiri dari :

- Laporan Realisasi Anggaran Pendapatan dan Belanja Desa (APBDesa)

- Catatan Laporan Keuangan

b. Laporan Realisasi Kegiatan

c. Daftar Program Sektoral, yaitu program Pemerintah Daerah dan Program lainnya yang masuk ke desa.

3. Menginformasikan Laporan Realisasi Pelaksanaan Anggaran Pendapatan dan Belanja Desa (APBDesa) dan Laporan Pertanggungjawaban Realisasi Pelaksanaan Anggaran Pendapatan dan Belanja Desa (APBDesa) kepada masyarakat (pasal 72).

Informasi yang disajikan kepada masyarakat paling sedikit harus memuat:

1. Laporan Realisasi Anggaran Pendapatan dan Belanja Desa (APBDesa)

2. Laporan Realisasi Kegiatan

3. Laporan Kegiatan yang belum selesai

4. Laporan Kegiatan yang tidak terlaksana

5. Laporan sisa anggran APBDesa

6. Alamat Pengaduan

\section{FAKTOR FAKTOR YANG MENJADI KENDALA DALAM PERTANGGUNG JAWABAN KEPALA DESA.}

Dalam Melaksanakan Tugas, Kewenangan, Hak dan kewajibannya berdasarkan Peraturan pemerintah nomor 43 tahun 2014 pasal 48, Kepala Desa wajib :

a. Menyampaikan laporan penyelenggaraan Pemerintahan desa pada akhir masa jabatan kepada Bupati/wali kota

b. Menyampaikan laporan penyelenggaraan Pemerintahan desa setiap akhir tahun Kepada Bupati /Walikota

c. Menyampaikan Laporan keterangan penyelenggaraan pemerintahan secara tertulis kepada Badan Permusyawaratan Desa setiap akhir tahun anggaran.

Desa dalam substansi makna yang tercantum dalam Undang Undang nomor 6 tahu 2014 adalah teritergrasi prinsip rekognasi dan otonomi yang menempatkan desa sebagai arena politik, Demokrasi, arena sosial, arena adat istiadat dan arena ekonomi. 
Derajat pengakuan desa oleh negara bukan melepaskkan desa dari alur kualitas desa dalam bernegara tetapi mendorongdan menempatkan desa sebagai identitas bernegara oleh sebab itu prinsip utama yang dikedepankan adalah State akuntability .

Persoalan persoalan yang menjadi faktor faktor yang menghambat pertanggungjawaban Kepala desa didalam mempertanggungjawabkan tugasnya sebagai penyelenggara pemerintahan desa adalah

a. Meningkatnya berbagai peran serta supra desa melakukan "Pengawasan dan Pembinaan" terhadap desa. Seperti adanya kerjasama Kementrian dalam Negeri dan Kepolisian Republik Indonesia terkait pengawasan dana desa.Adanya kerjasama antara kementrian desa dengan kejaksaan RI, BPK,KPK,dan perguruan Tinggi terkait pengawasan pelaksanaan pembangunan desa, Semua bentuk kerjasama itu diarahkan ke desa alhasil bukannya desa semakin kuat tetapi desa semakin terperdaya, sebab praktek empirik kerjasama tersebut, cenderung memperdaya desa.

Kasus di beberapa daerah, dimana desa, perangkat desa, kepala desa, seringkali jadi korban superioritas kewenangan supra desa. Misalnya praktek pemungutan pajak, praktek upeti, praktek pengawasan, praktek dana pengamanan pilkades, praktek pemeriksaan laporan kegiatan, dll.

Dimana semua tindakan kejahatan tersebut, dikelola dengan rapid an baik atas nama kerjasama pengawasan dan pembinaan. Kepala Desa, perangkat lagi lagi menjadi korban dalam skema Lporan Pertanggung jawaban desa.

b. Mengingat banyaknya muatan Laporan Materi Pertanggungjawaban Kepala Desa yang terdiri dari :

1. Pendahuluan

2. Program keja penyelenggaraan Pemerintah desa

3. Program Kerja pelaksanaan Pembangunan

4. Program kerja Pembinaan Kemasyarakatan

5. Program Kerja Pemberdayaan Masyarakat

6. Pelaksanaan Anggaran Pendapatan dan belanja desa

7. Keberhasilan yang dicapai, permasalahan yang dihadapi dan upaya yang ditempuh.

8. Penutup 
Dengan muatan yang begitu banyak dan rumit sehingga kepala desa kesulitan menyusun LPPD.sehingga memerlukan bantuan dari Camat, Dinas PMD, Tenaga Ahli dan Pendamping Desa yaitu meng edukasi melatih dan melakukan pemberdayaan terhadap seluruh penyelenggara pemerintah desa,

c. Kondisi geografis di beberapa desa khususnya didaerah pedalaman yang mana akses antar desa harus melalui jarak yang cukup jauh, transportasi yang sulit, ditambah sinyal jaringan telekomunikasi atau mengakses internet tidak ada.sehingga menghambat kelancaran proses pembuatan Laporan Pertanggungjawaban oleh kepala desa.

d. Hal lain yang seringkali menjadi kendala yaitu Rincian Anggaran pendapatandan Belanja desa dalam LPPD tersebut dimana uraian tentang : Pendapatan desa, belanja desa, (belanja desa atas 4 bidang kewenangan desa, serta belanja tak terduga).Dimana narasi narasi laporan, seringkali anomaly dengan kondisi lapangan.

e. Hambatan dalam pengelolaan dana desa karena adanya potensi korupsi penyelewengan penggunaan dana desa.

Berkaitan dengan adanya potensi penyelewengan dana desa oleh kepala desa karena dana yang dikelola cukup besar dan banyaknya hambatan dalam pengelolaan dana desa ini yang berakibat fatal bagi kelancaran Laporan Pertanggungjawaban Kepala Desa maka lembaga Indonesia Coruption Watch (ICW) bersama sama dengan Yayasan Pembangunan Ekonomi menggelar sekolah anti Korupsi (SAKTI) yang digelar untuk Kepala Desa dan aparatur pemerintah desa di wilayah di Larantuka, Flores,Flores Timur, Nusa Tenggara Timur yang berhasil menghimpun kendala kendala dalam seputar pengelolaan desa dan anggaran desa.pelaksanaan SAKTI Aparat pemerintah Desa ini berhasil mengidentifikasi hambatan dalam pengelolaan anggaran desa hal hal yang menjadi penyebab korupsi Sebagai berikut :

1. Minimnya Kompetensi Aparat desa termasuk kepala desa

2. Tidak adanya transparansi

3. Kurang adanya pengawasan Pemerintah, masyarakat dan desa

4. Maraknya penggelembungan (Markup)harga.

5. Adanya intervensi atasan.

6. Pelaksanaan Kegiatan fisik yang tidak sesuai dengan perencanaan 
7. Adanya kultur member barang/uang sebagai bentuk penghargaan/terimakasih.

8. Perencanaan sudah diatur sedemikan rupa (di setting) oleh kepala desa dan Badan Permusyawaratan Desa

9. Pengelolaan dana desa(DD) dan ADD tidak sesuai Rancangan Anggaran Biaya (RAB).

10. Belanja tidak sesuai RAB.

11. Tim Pengelola Kegiatan (TPK) menerima Fee dari penyedia material , spesifikasi tidak sesuai.

12. Minimnya pengetahuan aparat desadalam memahami aplikasi Sistim Keuangan Desa (SisKeuDes)

13. Nomenklatur kegiatan tidak/kurang sesuai dengan Permendesa tentang prioritas penggunaan DD

14. Stndarisasi harga barang dan jasa bervariasi antar desa.

15. Minimnya kesejateraan aparat pemerintah desa.

16. Belum terpenuhinya kesejahteraan aparatur desa.

Sedangkan Hambatan atau kendala dalam pengelolaan dana desa yang sangat berpengaruh pada penyelesaikan Laporan Pertanggungjawaban Kepala Desa adalah :

1. Belum adanya pelayanan terpadu satu pintu mengenai dana desa.

2. Pencairan masih membutuhkan rekomendasi Camat.

3. Keterlambatan Pencairan dana,Trnsfer dari rekening daerah ke rekening desa selalu terlambat.

4. Penundaan Pencairan dari Bank.

5. Dana di Bank tidak selalu tersedia sehingga memperlambat pencairan dana ke kas desa.

6. Lemahnya kapasitas Sumber daya Kepala desa dan perangkat desa

7. Kurangnya pendampingan dari fihak yang berwenang.

8. Partisipasi masyarakat masih rendah.

9. Pendekatan Perencanaan partisipasif tidak berjalan masih didominasi orang orang tertentu.

10. BPD kurang memahami tugas dan fungsinya

11. Miskomunikasi antara Pemdes dan BPD 
12. Terlambatnya RPJMD tahun $\mathrm{N}+1$ dan pagu Indikatif desa(butuh RPJMD untuk penyelarasan Program)

13. Asistensi Rancangan Anggaran pendapatan dan belanja desa(RAPBdes) tidak valid.

14. Kompetensi ASN minim dalam pendampingan pengelolaan dana desa.

15. Minimnya Kapasitas tenaga teknis desa dalam menyusun RAB.

16. Masih ada yang belum menggunakan aplikasi SisKeuDes.

17. Kondisi Sosial masyarakat.

18. Kurang tersedianya material local.

19. Koordinasi kurang berjalan maksimal

20. Penataan Administrasi masih dibutuhkan.

21. Keterbatasan SDM untuk diperbantukan di kepala seksi.

22. Manipulasi Pertanggungjawaban (LaporanTPK dan laporan keterangan pertanggungjawaban LPKJ Kepala desa).

Hambatan hambatan tersebut memang tidak seluruhnya ada disetiap desa namun tidak kita pungkiri memang sebagian besar benar dan sangat menjadi kendala dalam proses kelancaran Laporan Pertanggungjawaban kepala Desa.

\section{J. PERAN BADAN PEMUSYAWARATAN DESA DALAM KAITANNYA DENGAN PERTANGGUNGJAWABAN KEPALA DESA .}

Berdasarkan Peraturan pemerintah nomor 43 tahun 2014 pasal 48,butir c Kepala Desa wajib Menyampaikan Laporan keterangan penyelenggaraan pemerintahan secara tertulis kepada Badan Permusyawaratan Desa setiap akhir tahun anggaran.kepada Badan Permusyawaratan desa secara tertulis paling lambat tiga (3) bulan setelah berakhirnya tahun anggaran.

Laporan Keterangan penyelenggaraan pemerintah desa sebagaimana dimaksud digunakan oleh Badan Permusyawaratan Desa dalam melaksanakan fungsi pengawasan kinerja kepala desa.

Dari uraian diatas sudah jelas bahwa Badan Permusyawaratan Desa mempunyai peran Strategis dalam mengawal pengunaan dana desa agar tidak diselewengkan.

Karena Dana desa yang bersumber dari APBN jumlahnya cukup besar maka diperlukan mekanisme kontrol dari masyarakat untuk mengawasi penggunaan Dana 
desa tersebut agar dana tersebut dipergunakan sesuai peruntukannya untuk meningkatkan kesejahteraan masyarakat.Kepala desa dituntut untuk menyelenggarakan pemerintahan secara transparan dan Akuntable

Badan Permusyawaratan desa yang merupakan lembaga yang mempunyai fungsi pengawasan diharapkan bisa menjalankan perannya secara sungguh sungguh terutama dalam hal pengunaan anggaran, undang undang dan peraturan pemerintah sudah memberikan payung hukum yang jelas sehingga BPD tidak perlu ragu dalam menjalankan fungsinya.

\section{K. KESIMPULAN}

Faktor faktor yang menjadi kendala dalam pertanggungjawaban kepala desa

a. Desa dalam Substansi makna yang tercantum dalam makna UU nomor 16 tahun 2014 merupakan terintergrasi PrinsipRekognisi dan Otonomi yang menempatkan desa se -bagai arena politik, Arena Demokrasi, Arena Sosial dan arena adat istiadat dan arena ekonomi.

b. Memasuki periode 4 tahun implementasi UU Desa ada persoalan yang terjadi khususnya menyangkut tanggung jawab ber-Desa dalam koridor sebagai bagian dari tanggung jawab bernegara mulai dari persoalan malpraktik perencanaan, malpraktik anggaran, disfungsi kewenangan, disorientasi program hingga manipulasi proyek pembangunan desa.

c. Meningkatnya peran serta berbagai institusi melakukan pengawasan dan pembinaan sehingga desa lagi-lagi menjadi korban dalam skema laporan substansi pertanggung jawaban desa dalam narasi tata kelola pemerintahan, ada kewajiban bagi pemerintah desa untuk menyusun perencanaan pembangunan desa, melaksanakan dan melaporkan (mempertanggung jawabkan) secara konstitusional.

d. Adanya Penyelewengan penggunaan anggaran desa yang mengarah pada tindak korupsi dan juga Hambatan kemampuan Sumberdaya manusia dalam Penglolaan dana desa.

e. Kondisi geografis di beberapa desa khususnya didaerah pedalaman yang mana akses antar desa harus melalui jarak yang cukup jauh , transportasi 
f. yang sulit, ditambah sinyal jaringan telekomunikasi atau mengakses internet tidak ada.sehingga menghambat kelancaran proses pembuatan Laporan Pertanggungjawaban oleh kepala desa.

g. Badan Pemusyawaratan Desa yang merupakan lembaga yang mempunyai fungsi pengawasan diharapkan bisa menjalankan perannya secara sungguh sungguh terutama dalam hal penggunaan anggaran dana desa, Badan Permusyawaratan Desa mempunyai peran yang strategis dalam ikut mengawal penggunaan dana desa agar tidak diselewengkan oleh sebab itu Kepala Desa wajib menyampaikan Laporan Keterangan Penyelengaraan Pemerintahan secara tertulis kepada Badan Permusyawaratan Desa setiap akhir tahun anggaran, seperti yang diatur dalam Peraturan Pemerintah nomor 43 tahun 2014 pasall 48.

\section{DAFTAR PUSTAKA}

Andi Mustari Pide, Otonomi Daerah Dan Kepala Daerah Memasuki Abad XXI Gaya Media Ilmu, Jakarta, 1999

Biro Pemerintah Sekertariat Wilayah/Tingkat I, Keputusan Mentri Dalam Negeri Nomor 63, 64, Dan 65, 1999

Bambang Sunggono, Metode Penelitian Hukum, Rajagrafindo Persada, Jakarta2002. Departemen Dalam Negeri Ri, Undang-Undang Pemerintah Daerah Dan UndangUndang Perimbangan Keuangan Antara Pusat Dan Daerah, Jakarta, 1999

Kansil, System Pemerintahan Indonesia, Bumi Aksara, 1995

Imam Sudiyat, Azaz-Azaz Hokum Adat, Liberty, Yogjyakarta, 2000

Pengaturan Desa Dan Kelurahan, Kuraiko Pratama, Bandung, 2000

Philipus M. Hadjon, Penghantar Hukum Administrasi Indonesia, Gadjah Mada University Press, Yogyakarta, 1999

Soerjono Soekanto, Penghantar Penelitian Hukum, Universitas Indonesia Press, Jakarta, 2000.

Suhartono, Parlemen Desa Dinamika Dpr Kelurahan Dan Dprk Gotong Royong, Lampera Pustaka Utama, Yogyakarta, 2000.

Tim Progam Peningkatan Penaran Masyrakat Otonom Daerah Dan Good Govermance, Panduan Penguatan Bpd, Jawa Timur 2002 
Yan Pramadya Puspa, Kamus Hukum Bahasa Belanda, Indonesia, Inggris, Aneka Ilmu, Semarang 1977.

Undang Undang nomor 6 tahun2014 tentang Pemerintahan Desa.

Undang Undang nomor 23 tahun2014 tentang Pemerintahan Daerah

Peraturan Menteri Dalam Negeri (Permendagri) nomor 10 Tahun 2015.

Peraturan Pemerintah nomor 43 tahun 2014 Tentang Badan Permusyawaratan Desa(BPD) 